\title{
Effect of Potassium Humate and Boron Fertilization Levels on Yield and Quality of Sugar Beet in Sandy Soil
}

\author{
Hitham E.A. Nemeat-Alla ${ }^{1}$, Ibrahim S.H. El-Gamal ${ }^{2}$ and Nadia K. El-Safy ${ }^{2}$ \\ ABSTRACT

\section{INTRODUCTION}

To study the effect of different levels of potassium humate and boron fertilization, two field trials were carried out in a private farm at El-Nubaria region, (latitude of $30.86^{\circ} \mathrm{N}$, longitude of $31.16^{\circ} \mathrm{E}$ and altitude of $21 \mathrm{~m}$ above sea level) El-Bahira Governorate, Egypt in $2018 / 2019$ and $2019 / 2020$ seasons. This work included sixteen treatments, represent the combinations of four levels of potassium humate as a soil application $(0,2.5,5$ and $7.5 \mathrm{~kg} / \mathrm{fed}$ ) and four levels of boron (zero, 70, 140 and $210 \mathrm{ppm} / \mathrm{fed}$ ) as a foliar application in the form of boric acid $17 \%$ boron), which sprayed thrice at 50, 65 and 80 days from sowing and their effect on growth, yield and quality of sugar beet (Beta vulgaris var. saccharifera, L.). A split-plot design in three replications was done.

The results revealed that fertilizing sugar beet with $\mathbf{7 . 5}$ $\mathrm{kg}$ potassium humate resulted in higher values of leaf area index (LAI), photosynthetic pigments, root diameter, fresh and foliage weights/plant, sucrose, sugar lost to molasses, extractable sugar percentages, quality index, root and sugar yields/fed in both seasons. However, the sodium content of roots was insignificantly affected by the studied potassium humate levels in both seasons.

It was found that higher values of leaf area index (LAI), root diameter, fresh and foliage weights/plant, sucrose, sugar lost to molasses, sugar extractable percentages and quality index, as well as root, top and sugar yields/fed, were obtained with increasing boron application to $210 \mathrm{ppm} / \mathrm{fed}$. otherwise, photosynthetic pigments, $\mathrm{K}, \mathrm{Na}$ and alfa-amino $\mathrm{N}$ contents were insignificantly affected by the applied boron levels in both seasons.

Fertilizing beet plants with $7.5 \mathrm{~kg}$ potassium humat/fed +210 ppm boron resulted in a significant increase of LAI, chlorophyll (a), (b), root diameter and yield/fed compared to other combinations in both seasons.

Under conditions of this work, the maximum root and sugar yields/fed were obtained by fertilizing beets with 7.5 kg potassium humate/fed as a soil application and spraying beets with $210 \mathrm{ppm}$ boron/fed at three times $(50,65$ and 80 days) after sowing.

Keywords: Boron, potassium humate levels, sugar beet in sandy soil.
Sugar beet (Beta vulgaris L.) belongs to the Chenopodiaceae family. It is considered one of the main sources of sugar production in Egypt and the importance of this crop comes from its growth in the newly reclaimed lands and taproot contains a high concentration of sucrose. The production of sugar from sugar beet reached $(62.1 \%)$ of total sugar production in Egypt. Improvement of sugar beet production can be achieved through optimizing the potassium humate and boron fertilization levels. Potassium Humate improves the soil structure, promotes fertilizer efficiency, increases capacities of water holding and cation exchange, stimulates plant growth and root development Hartwigsen and Evans (2000). In this connection, Shaban et al., (2014) reported that adding $10 \mathrm{~kg}$ potassium humate/fed as a soil application increased sucrose $\%$, root and sugar yields/fed in both seasons compared with untreated treatment. Enan et al., (2016) manifested that the highest values of leaf are index, root and foliage fresh weight/ plants in addition to the root, top and sugar yields /fed. were achieved when fertilizing sugar beet at the rate of 151 humic/fed as a soil drench in both seasons. Nemeat Alla et al., (2018) concluded that adding 81 potassium humate/fed had a positive effect on plant growth, sucrose, root and sugar yields/fed in both seasons. Rehab et al., (2019) noticed that increasing potassium humate level from zero up to $6 \mathrm{~kg} / \mathrm{fed}$ led to increasing root potassium content, yields of root and sugar/fed compared to unfertilized plants. while extractable sugar\%, sodium and alpha-amino nitrogen contents decreased in both seasons.

Mineral nutrition of plants is important for controlling the physiological and biochemical processes of plants. Their deficiency may lead to changes in these processes and disturbed plant growth and yield. Boron is considered an important nutrient not only to increase sucrose \% but also plays an important function in the translocation of sucrose from leaves to roots and other roles as cell divisions, water relations, respiration, The main functions of boron relate to cell wall strength, cell division and its development as well as, stimulation or inhibition of specific metabolism pathways. in this connection, Enan (2011) explained that increasing the

\footnotetext{
DOI: 10.21608/asejaiqjsae.2021.171635

${ }^{1}$ Agron., Res., Dept., Sugar Crops Res. Inst., Agric. Res. Center, Giza, Egypt. ${ }^{2}$ physiology., Res. Dept., Sugar Crops Res. Inst., Agric. Res. Center, Giza, Egypt. Received April 08, 2021, Accepted, May 15, 2021.
} 
rate of spraying with boron up to $200 \mathrm{ppm}$ had a positive effect on root diameter, fresh weight/plant, root, top and sugar yields/fed, sucrose\%. Abbas et al., (2014) showed that the highest values of sucrose, extractable sugar percentages, sugar yield/fed, and quality index were obtained by increasing boron level up to $20 \mathrm{~g} / 1$ compared to the check treatment. Mekdad (2015) spraying beets with $150 \mathrm{ppm}$ boron significantly improved sucrose, extractable sugar percentages and root yield/fed in both seasons. On contrarily $\mathrm{Na}, \mathrm{K}, \alpha-$ amino $\mathrm{N}$ contents and sugar lost to molasses\% decreased. Enan et al., (2016) concluded that spraying boron at $150 \mathrm{ppm} / \mathrm{fed}$ in sandy soil significant effect on Chlorophyll a, chlorophyllb, root diameter, fresh weight/plant, sucrose, extractable sugar percentages and quality index as well as root, top and sugar yields/fed, Nemeat Alla (2017) cleared that spraying sugar beet with $150 \mathrm{ppm}$ boron/fed increased root diameter, fresh and foliage weights/plant, top, root and sugar yields/fed, as well as quality index and extractable sugar\%. Otherwise, impurities contents $(\mathrm{K}, \mathrm{Na}, \alpha$ - aminonitrogen), and sugar lost to molasses $\%$ decreased. Pirzad et al., (2019) indicated that increasing nanoboron levels up to $4 \mathrm{~g}$ 1/fed resulted in the highest yields of root and sugar/fed and technological sugar (144.5, 28.2, 26.1 and 25.3 t/ha). Otherwise, impurities ( $\mathrm{Na}, \mathrm{K}$, $\alpha$-aminoN) contents and sugar lost molasses\% decreased. Shritinnahar et al., (2020) supplying sugar beet with four levels of boron (zero, 50,100 and 150 ppm), Application of $150 \mathrm{ppm}$ increased growth traits, sucrose $\%$ and quality index, as well the most effective for maximizing root and top yields/fed when it was sprayed applied thrice at 40, 65 and 90 days from sowing.

\section{MATERIAL AND METHODS}

Two field trials were carried out in a private farm at El-Nubaria region, (latitude of $30.86^{\circ} \mathrm{N}$, longitude of $31.16^{\circ} \mathrm{E}$ and altitude of $21 \mathrm{~m}$ above sea level).El-Bahira Governorate, Egypt in 2018/2019 and 2019/2020 seasons to study the effect of different levels of potassium humate and boron fertilization on growth, yield and quality of sugar beet. This work included sixteen treatments, represent the combinations of four levels of potassium humate $10 \% \mathrm{~K}_{2} \mathrm{O}^{\prime \prime}(0,2.5,5$ and 7.5 $\mathrm{kg} / \mathrm{fed}$ ) as a soil application and four levels of boron (zero, 70, 140 and $210 \mathrm{ppm} / \mathrm{fed}$ ) in the form of boric acid $17 \%$ boron), which sprayed thrice at 50,65 and 80 days from sowing. A split-plot design in three replications was done. The four rates applied of potassium humate fertilization allocated in the main plots and the four levels spraying of boron were randomly distributed in the sub-plots. Plot area was 28.8 $\mathrm{m}^{2}$, which included 8 ridges of $6.0 \mathrm{~m}$ in length and 0.6 $\mathrm{m}$ in width and $20 \mathrm{~cm}$ between hills.

Table 1. Soil properties of the experimental site in 2018/2019 and 2019/2020 seasons

\begin{tabular}{|c|c|c|}
\hline Season & $2018 / 2019$ & $2019 / 2020$ \\
\hline Sand\% & 51.75 & 52.53 \\
\hline Silt $\%$ & 25.84 & 23.46 \\
\hline Clay\% & 22.41 & 24.01 \\
\hline Soil texture & \multicolumn{2}{|c|}{ Sandy loam } \\
\hline $\mathrm{EC}(\mathrm{dS} / \mathrm{m})$ & 3.62 & 3.37 \\
\hline $\mathrm{pH}(1: 2.5)$ & 8.24 & 8.31 \\
\hline $\mathrm{OM}(\%)$ & 0.30 & 0.38 \\
\hline \multicolumn{3}{|c|}{ Cations (meq/l) } \\
\hline $\mathrm{Mg}^{++}$ & 4.00 & 3.50 \\
\hline $\mathrm{Na}^{+}$ & 19.83 & 20.11 \\
\hline $\mathrm{Ca}^{++}$ & 8.00 & 8.15 \\
\hline $\mathrm{K}^{+}$ & 3.36 & 2.99 \\
\hline \multicolumn{3}{|c|}{ Anions (meq/l) } \\
\hline $\mathrm{HCO}_{3}^{-}$ & 5.52 & 4.53 \\
\hline $\mathrm{Cl}^{-}$ & 24.00 & 24.22 \\
\hline $\mathrm{SO}^{-}$ & 5.67 & 6.00 \\
\hline \multicolumn{3}{|c|}{ Available NPK (mg/kg soil) } \\
\hline $\mathrm{N}$ & 39.97 & 42.60 \\
\hline $\mathrm{P}$ & 2.51 & 3.74 \\
\hline $\mathrm{K}$ & 141.40 & 158.00 \\
\hline Available boron (ppm) & 19 & 24 \\
\hline
\end{tabular}


Phosphorous was added in the form of superphosphate $(15 \%)$ at the rate of $30 \mathrm{~kg} \mathrm{P}_{2} \mathrm{O}_{5} / \mathrm{fed}$ during seedbed preparation. Nitrogen fertilizer was applied at $100 \mathrm{~kg}$ $\mathrm{N} / \mathrm{fed}$ as ammonium nitrate $(33.5 \% \mathrm{~N})$ in four equal doses; the $1^{\text {st }}$ was applied after thinning (4 true leaf stage) and another three ones were given at two-week intervals, after the first one. Potassium humate was mixed with experimental soil. Potassium humate was purchased from (Egyptian market, leonardite origin) and its analysis was showed that contented: (humic acid $85 \%$; fulvic acid $0.8 \% ; \mathrm{K}_{2} \mathrm{O} 4 \%$ ) and available of (nitrogen 0,7\%; $\mathrm{P}_{2} \mathrm{O}_{5} 0.06 \%$; $\mathrm{Ca} 0.89 \% ; \mathrm{Mg} \mathrm{0.29 \% ;} \mathrm{Fe}$ $0.89 \%$; Mn $0.043 \%$; Zn 0.013\%; Cu $0.056 \%$; boron 0.048 and soluble matter 5\%). Multigerm sugar beet variety viz "Magribel" was sown in the $2^{\text {nd }}$ week of September in both seasons, while harvesting took place at age of 210 days after sowing in both seasons.

Some soil physical properties of the soil were analyzed using the procedure described by Black et al. (1981). Soil chemical analysis was determined according to the method of Jackson (1973). Physical and chemical analyses of the soil (the upper $30 \mathrm{~cm}$ ) of the experimental site are given in Table 1.

\section{The recorded data:}

Leaf area $\left(\mathrm{cm}^{2}\right)$ was measured using a Li-Cor area meter LI-3000 (Li-Cor. Inc., Linclon, Nebraska, USA).

Photosynthetic pigments i.e., chlorophyll a,b and carotenoids $(\mathrm{mg} / \mathrm{g}$ leaf fresh weight0were determined according to the methods described by Wettstein (1957).

At harvest, a sample of fifteen plants was randomly collected from the middle rows of each plot to determine the following traits:

1. Root diameter $(\mathrm{cm})$.

2. Root and foliage fresh weight/plant $(\mathrm{g})$

3. Impurities (potassium, sodium and $\alpha$-amino $\mathrm{N}$ ) in roots were estimated as meq/100 $\mathrm{g}$ beet, where determined in El- Nubarea Sugar Company Laboratories at El-Behira Governorate, by an Automated Analyzer as described by Cooke and Scott (1993).

4. Sucrose (Pol \%) was estimated in the fresh samples of sugar beet roots using Saccharometer according to the method described by A.O.A.C. (2005).

5. Sugars lost to molasses percentage (SLM \%) was calculated according to the following formula as shown by Devillers (1988):

$$
\mathrm{SLM} \%=0.14(\mathrm{Na}+\mathrm{K})+0.25(\alpha-\operatorname{amino} \mathrm{N})+0.5
$$

6. Extracted sugar percentage was calculated according the formula of Dexter et. al. (1967) as follows:

Extracted sugar $\%=$ sucrose $\%$ - SLM $\%-0.6$

7. Quality index (QI\%) was calculated using the equation as follows:

$$
\mathrm{QI}=(\text { extracted sugar \% / sucrose } \%) \times 100 \text {. }
$$

8. Root and top yields/fed (ton), which were determined on sub plot weight $(\mathrm{kg})$ and converted to tons/fed.

9. Sugar yield/fed (ton) was calculated according to the following equation:

Sugar yield/fed (ton) $=($ root yield/fed (ton) $\mathrm{x}$ extracted sugar \%) / 100

\section{Statistical analysis:}

All obtained data were statistically analyzed according to the technique of analysis of variance (ANOVA) for A split plot design as published by Gomez and Gomez (1984) using (MSTAT-c) computer software package. The least significant difference (LSD) was used to test the differences between treatment means at 5\% level of probability as described by Snedecor and Cochran (1980).

\section{RESULTS AND DISCUSSION}

\section{Leaf area index, chlorophyll (a), chlorophyll (b) and carotenoids}

Data in Table 2 clarified that raising potassium humate level from zero to $7.5 \mathrm{~kg} / \mathrm{fed}$ resulted in a significant increase in leaf area index amounted to 1.08 in sugar beet fertilized with $7.5 \mathrm{~kg} / \mathrm{fed}$ over that those unfertilized with K-humate in ' ${ }^{\text {st }}$ season. However, this increase was 1.46, in the second season. As well, fertilizing beet plants with a high dose of K-humate/fed attained increases in values of photosynthetic pigments amounted to $(0.40,0.53$ in chlorophyll a), $(0.36,0.31$ in chlorophyll b) and amounted to $(0.14,0.15$ increases in carotenoids) in $1^{\text {st }}$ and $2^{\text {nd }}$ season, respectively as compared to fertilizing beets with $5 \mathrm{~kg} \mathrm{~K}$-humate/fed. The appreciable influence of potassium humate may be attributed to its effect in increasing the photosynthetic surface per unit area which, promoted growth and nutrient uptake of plants by the addition of humic substances which affect membrane permeability which has a direct relation with leaf chlorophyll concentration. The aforementioned results generally are in good agreement with those stated by Enan et al., (2016) and Nemat Alla et al., (2018). 
Table 2. Leaf area index, chlorophyll a, $b$ and carotenoids concentrations (mg/g leaf fresh weight) of sugar beet as affected by potassium humate and boron fertilizer treatments in 2018/2019 and 2019/2020 seasons-

\begin{tabular}{|c|c|c|c|c|c|c|c|c|}
\hline \multirow{3}{*}{ Treatments } & \multirow{2}{*}{\multicolumn{2}{|c|}{ Leaf area index }} & \multicolumn{6}{|c|}{ Photosynthetic pigments (mg/g f.w.) } \\
\hline & & & \multicolumn{2}{|c|}{ Chlorophyll a } & \multicolumn{2}{|c|}{ Chlorophyll b } & \multicolumn{2}{|c|}{ Carotenoids } \\
\hline & $\begin{array}{c}1^{\text {st }} \\
\text { Season } \\
\end{array}$ & $\begin{array}{c}2^{\text {nd }} \\
\text { Season } \\
\end{array}$ & $\begin{array}{c}1^{\text {st }} \\
\text { Season } \\
\end{array}$ & $\begin{array}{c}2^{\text {nd }} \\
\text { Season } \\
\end{array}$ & $\begin{array}{c}1^{\text {st }} \\
\text { Season } \\
\end{array}$ & $\begin{array}{c}2^{\text {nd }} \\
\text { season } \\
\end{array}$ & $\begin{array}{c}1^{\text {st }} \\
\text { Season } \\
\end{array}$ & $\begin{array}{c}2^{\text {nd }} \\
\text { Season } \\
\end{array}$ \\
\hline & & $(\mathrm{A})$ & \multicolumn{6}{|c|}{ Potassium humate rate $(\mathrm{kg} / \mathrm{fed})$} \\
\hline 0 & 2.26 & 2.31 & 1.58 & 1.29 & 0.62 & 0.69 & 0.38 & 0.36 \\
\hline 2.5 & 2.46 & 2.58 & 1.89 & 1.67 & 0.86 & 0.85 & 0.53 & 0.61 \\
\hline 5 & 3.17 & 3.58 & 2.05 & 1.95 & 1.13 & 1.15 & 0.69 & 0.76 \\
\hline 7.5 & 3.34 & 3.77 & 2.45 & 2.48 & 1.49 & 1.46 & 0.83 & 0.91 \\
\hline LSD at $5 \%$ & 0.14 & 0.32 & 0.25 & 0.28 & 0.18 & 0.16 & 0.14 & 0.18 \\
\hline \multicolumn{9}{|c|}{ (B) Boron fertilization level (ppm) } \\
\hline 0 & 2.32 & 2.75 & 1.90 & 1.70 & 0.90 & 0.92 & 0.57 & 0.60 \\
\hline 70 & 2.47 & 2.94 & 1.92 & 1.76 & 0.97 & 0.97 & 0.59 & 0.64 \\
\hline 140 & 3.16 & 3.17 & 2.03 & 1.88 & 1.09 & 1.10 & 0.62 & 0.70 \\
\hline 210 & 3.27 & 3.38 & 2.12 & 2.06 & 1.18 & 1.21 & 0.67 & 0.72 \\
\hline LSD at $5 \%$ level & 0.11 & 0.21 & NS & NS & NS & NS & NS & NS \\
\hline $\mathrm{AxB}$ & 0.21 & 0.44 & 0.15 & 0.19 & 0.18 & 0.15 & NS & NS \\
\hline
\end{tabular}

As for, the effect of boron levels, data in the same Table cleared that fertilizing sugar beet with $210 \mathrm{ppm}$ of boron led to the positive effects of leaf area index, comparing with (untreated beets and those that received $70 \mathrm{ppm}$ boron/fed) whilst, insignificant differences between boron levels in their impact on photosynthetic pigments in both seasons. At the same time, it was found that leaf area index reduced when spraying beets with low doses (without and $70 \mathrm{ppm}$ of boron/fed) which, is reflected in the root, top fresh weights/plant. This result may be due to the role of the boron element in cell elongation where, in case of boron deficiency the leaves are smaller, stiff and thick also their role for the formation of new leaves. Moreover, it has an active role in the translation of the assimilation product of the leaves and roots. Similar results were reported by Enan (2011) and Shritinnahar et al., (2020).

\section{Interaction effect:}

Among the studied traits leaf area index/plant was significantly affected by the interaction between potassium humate levels and boron fertilization rates in both seasons. Data in Table 3 indicated that the difference in leaf area index/plant between beets sprayed with $140 \mathrm{ppm}$ of boron and those supplied with 210 was insignificant when plants were fertilized with $2.5,5$ and $7.5 \mathrm{~kg}$ humate/fed, however, the variance in LAI between those two levels of boron was significant under conditions of the other humate treatments, in the first and second season. At the same time, adding 7.5 $\mathrm{kg} / \mathrm{fed}$ of humate was significantly more responsive than soil drench by $5 \mathrm{~kg} / \mathrm{fed}$ due to leaf area index. This may be due to increasing the photosynthetic surface per unit area which, promoted growth and nutrient uptake of plants along with the applied boron, which affects membrane permeability Enan et al., (2016).

Table 3. Effect of interaction between potassium humate and boron fertilization levels on leaf area index in 2018/2019 and 2019/2020 seasons

\begin{tabular}{ccccccccc}
\hline & \multicolumn{4}{c}{ Boron fertilization levels (ppm/fed) } \\
\cline { 2 - 9 } Potassium humate rate (kg/fed) & \multicolumn{4}{c}{$\mathbf{1}^{\text {st }}$ season } & \multicolumn{5}{c}{$\mathbf{2}^{\text {nd }}$ season } \\
\cline { 2 - 9 } & $\mathbf{0}$ & $\mathbf{7 0}$ & $\mathbf{1 4 0}$ & $\mathbf{2 1 0}$ & $\mathbf{0}$ & $\mathbf{7 0}$ & $\mathbf{1 4 0}$ & $\mathbf{2 1 0}$ \\
\hline 0 & 1.67 & 1.75 & 2.73 & 2.89 & 1.65 & 1.92 & 2.62 & 3.04 \\
2.5 & 1.99 & 2.01 & 2.89 & 2.96 & 2.49 & 2.56 & 2.60 & 2.65 \\
5 & 2.69 & 2.95 & 3.49 & 3.56 & 3.17 & 3.51 & 3.65 & 3.98 \\
7.5 & 2.93 & 3.18 & 3.57 & 3.67 & 3.68 & 3.78 & 3.79 & 3.83 \\
\hline LSD at 5\% level & \multicolumn{4}{c}{0.21} & \multicolumn{5}{c}{0.34} \\
\hline
\end{tabular}


Table 4. Effect of interaction between potassium humate and boron fertilization levels on chlorophyll (a) in 2018/2019 and 2019/2020 seasons

\begin{tabular}{cccccccccc}
\hline & \multicolumn{4}{c}{ Boron fertilization levels (ppm/fed) } \\
\cline { 2 - 9 } Potassium humate rate (kg/fed) & \multicolumn{4}{c}{$\mathbf{1}^{\text {st }}$ season } & \multicolumn{4}{c}{$\mathbf{2}^{\text {nd }}$ season } \\
\cline { 2 - 9 } & $\mathbf{0}$ & $\mathbf{7 0}$ & $\mathbf{1 4 0}$ & $\mathbf{2 1 0}$ & $\mathbf{0}$ & $\mathbf{7 0}$ & $\mathbf{1 4 0}$ & $\mathbf{2 1 0}$ \\
\hline 0 & 1.53 & 1.55 & 1.60 & 1.64 & 1.11 & 1.13 & 1.41 & 1.51 \\
2.5 & 1.79 & 1.83 & 1.93 & 2.04 & 1.60 & 1.65 & 1.68 & 1.77 \\
5 & 2.00 & 2.03 & 2.05 & 2.13 & 1.88 & 1.91 & 1.93 & 2.09 \\
7.5 & 2.28 & 2.30 & 2.54 & 2.70 & 2.23 & 2.33 & 2.50 & 2.87 \\
\hline LSD at 5\% level & \multicolumn{4}{c}{0.16} & \multicolumn{5}{c}{0.19} \\
\hline
\end{tabular}

Table 5. Effect of interaction between potassium humate and boron fertilization levels on chlorophyll (b) in 2018/2019 and 2019/2020 seasons

\begin{tabular}{cccccccccc}
\hline & \multicolumn{4}{c}{ Boron fertilization levels (ppm/fed) } \\
\cline { 2 - 9 } Potassium humate rate (kg/fed) & \multicolumn{4}{c}{$\mathbf{1}^{\text {st }}$ season } & \multicolumn{4}{c}{$\mathbf{2}^{\text {nd }}$ season } \\
\cline { 2 - 9 } & $\mathbf{0}$ & $\mathbf{7 0}$ & $\mathbf{1 4 0}$ & $\mathbf{2 1 0}$ & $\mathbf{0}$ & $\mathbf{7 0}$ & $\mathbf{1 4 0}$ & $\mathbf{2 1 0}$ \\
\hline 0 & 0.50 & 0.59 & 0.67 & 0.74 & 0.53 & 0.69 & 0.77 & 0.80 \\
2.5 & 0.80 & 0.85 & 0.89 & 0.92 & 0.82 & 0.76 & 0.89 & 0.93 \\
5 & 1.00 & 1.12 & 1.14 & 1.29 & 1.00 & 1.15 & 1.17 & 1.31 \\
2.5 & 1.30 & 1.37 & 1.56 & 1.76 & 1.33 & 1.29 & 1.54 & 1.70 \\
\hline LSD at 5\% level & \multicolumn{4}{c}{0.18} \\
\hline
\end{tabular}

Chlorophyll (a) and (b) are the two major pigments, involved in photosynthesis. Chlorophyll (a) is the primary pigment of photosynthesis, trapping light energy Chlorophyll (b) is the accessory pigment, passing the trapped energy into chlorophyll (a). Thus, the main difference between chlorophyll $\mathrm{A}$ and $\mathrm{B}$ is their functions in photosynthesis. Accordingly, the results in Tables 4 and 5 revealed that the abovementioned photosynthetic pigments were responded to the increase of potassium humate level, but were highly content in beet leaf tissue by adding $210 \mathrm{ppm}$ boron/fed. Therefore, the highest value of leaves content of chlorophyll (a) and (b) was recorded by fertilizing beet plants $7.5 \mathrm{~kg}$ K-humate/fed and $210 \mathrm{ppm}$ boron in both seasons. This finding may be due to humic substance and potassium role that induce the physiological activities and increase total chlorophyll in plants which, reflects on the activity of photosynthesis which will positively reflect on the growth characteristics Shaban et al., (2014).

\section{Root diameter, fresh and foliage weights/plant}

Root diameter, fresh and foliage weights/plant were increased significantly as the soil-applied potassium humate level was raised from zero up to $7.5 \mathrm{~kg} / \mathrm{fed}$ in both seasons Table 6 . Application of $7.5 \mathrm{~kg}$ humate/fed increased both root diameter, fresh and foliage weights/plant amounted to $(1.83 \mathrm{~cm}, 139.33 \mathrm{~g}$ and 59.34 g) successfully, in $1^{\text {st }}$ season and $(2.11 \mathrm{~cm}, 69.08 \mathrm{~g}$ and $33.92 \mathrm{~g}$ ) respectively, in $2^{\text {nd }}$ season over that fertilized with $5 \mathrm{~kg}$ potassium humate/fed. These increases in the above-mentioned traits may be due to humate and potassium effect where the mechanism of humic acid is mainly the formation of a complex between the acidic and the mineral elements, and also plays a key role in the process of photosynthesis and respiration, and stimulating nucleic acid metabolism Curcic et al. (2018). As well as positive potassium effect in physiological processes in the plant such as respiration, transpiration, translocation of sugars and carbohydrates, energy transformation and active enzyme actions Shaban et al., (2014) and Nemeat Alla et al. (2018).

Data in the same Table revealed that root diameter, fresh and foliage weights/plant were significantly affected by foliar-applied boron level. Spraying beet plants with $210 \mathrm{ppm}$ boron/fed gave an increasing root diameter, fresh and foliage weights/plant in both seasons. The thickest, heaviest weight of roots and foliage's obtained maybe point to the importance role of the boron element concerning its effect on beet growth especially root tips, new leaves, as well sugar accumulation as a transformation catalyst, which in turn reflected on the evaluation of the aforementioned traits. These findings agree with those mentioned by Abbas et al., (2014) and Shritinnahar et al., (2020). 
Table 6. Effect of potassium humate and boron fertilization levels on root diameter, fresh and foliage weights/plant of sugar beet in 2018/2019 and 2019/2020 seasons

\begin{tabular}{|c|c|c|c|c|c|c|}
\hline \multirow{2}{*}{ Treatments } & \multicolumn{2}{|c|}{$\begin{array}{l}\text { Root diameter } \\
(\mathbf{c m})\end{array}$} & \multicolumn{2}{|c|}{$\begin{array}{l}\text { Root fresh weight/plant } \\
\text { (g) }\end{array}$} & \multicolumn{2}{|c|}{$\begin{array}{l}\text { Foliage fresh weight/plant } \\
(\mathrm{g})\end{array}$} \\
\hline & $\begin{array}{c}1^{\text {st }} \\
\text { season }\end{array}$ & $\begin{array}{c}2^{\text {nd }} \\
\text { season }\end{array}$ & $\begin{array}{c}1^{\text {st }} \\
\text { season }\end{array}$ & $\begin{array}{c}2^{\text {nd }} \\
\text { season }\end{array}$ & $1^{\text {st }}$ season & $2^{\text {nd }}$ season \\
\hline \multicolumn{7}{|c|}{ (A) Potassium humate rate $(\mathrm{kg} / \mathrm{fed})$} \\
\hline 0 & 7.10 & 8.33 & 375.67 & 450.75 & 252.42 & 261.92 \\
\hline 2.5 & 8.23 & 9.38 & 462.17 & 549.83 & 269.58 & 294.83 \\
\hline 5 & 9.46 & 10.42 & 564.50 & 583.92 & 311.83 & 330.08 \\
\hline 7.5 & 11.29 & 12.53 & 703.83 & 653.00 & 371.17 & 364.00 \\
\hline LSD at $5 \%$ level & 0.67 & 0.60 & 77.15 & 35.21 & 52.47 & 30.35 \\
\hline \multicolumn{7}{|c|}{ (B) Boron fertilization level (ppm) } \\
\hline 0 & 8.51 & 9.68 & 471.67 & 527.33 & 273.42 & 285.92 \\
\hline 70 & 8.93 & 9.90 & 511.17 & 549.33 & 290.42 & 298.25 \\
\hline 140 & 9.12 & 10.23 & 550.08 & 568.58 & 311.08 & 325.08 \\
\hline 210 & 9.53 & 10.86 & 573.25 & 592.25 & 330.08 & 341.58 \\
\hline LSD at $5 \%$ level & 0.30 & 0.41 & 21.57 & 19.42 & 20.71 & 8.38 \\
\hline $\mathrm{AxB}$ & 0.61 & 0.83 & $\mathrm{NS}$ & NS & $\mathrm{NS}$ & NS \\
\hline
\end{tabular}

\section{Interaction effect:}

Root diameter was significantly affected by the interaction between potassium humate and boron fertilization levels Table 7 . There was an insignificant difference between beets sprayed with 140 of boron and those sprayed with $210 \mathrm{ppm}$, when plants were unfertilized, as well fertilized with 2.5 and $5 \mathrm{~kg} / \mathrm{fed}$ potassium humate. However, the variance in root diameter between these two levels of boron was significant under the application of $7.5 \mathrm{~kg} / \mathrm{fed}$ potassium humate/fed in both seasons. Supplying beets with a combination of $7.5 \mathrm{~kg}$ potassium humate/fed along with $210 \mathrm{ppm}$ boron/fed recorded the highest values root diameter in both seasons. These results may be due to boron deficiency at the experimental site during growth stages therefore, its effect on photosynthates translocation from leaves to roots.

Table 7. Effect of interaction between potassium humate and boron fertilization levels on root diameter in 2018/2019 and 2019/2020 seasons

\begin{tabular}{cccccccccc}
\hline & \multicolumn{6}{c}{ Boron fertilization level (ppm /fed) } \\
\cline { 2 - 9 } Potassium humate rate (kg/fed) & \multicolumn{4}{c}{ 1st season } & \multicolumn{4}{c}{ 2nd season } \\
\cline { 2 - 9 } & $\mathbf{0}$ & $\mathbf{7 0}$ & $\mathbf{1 4 0}$ & $\mathbf{2 1 0}$ & $\mathbf{0}$ & $\mathbf{7 0}$ & $\mathbf{1 4 0}$ & $\mathbf{2 1 0}$ \\
\hline 0 & 7.01 & 7.07 & 7.12 & 7.20 & 8.12 & 8.18 & 8.31 & 8.72 \\
2.5 & 7.87 & 8.00 & 8.15 & 8.91 & 9.15 & 8.88 & 9.32 & 10.16 \\
5 & 9.17 & 9.39 & 9.54 & 9.72 & 10.20 & 10.22 & 10.57 & 10.70 \\
7.5 & 9.98 & 11.25 & 11.65 & 12.28 & 11.22 & 12.33 & 12.73 & 13.86 \\
\hline LSD at 5\% level & \multicolumn{4}{c}{0.61} & \multicolumn{5}{c}{0.83} \\
\hline
\end{tabular}


3. Sucrose\% and impurities contents (meq/100 $\mathrm{g}$ beet)

Except for sodium content, data in Table 8 revealed that sucrose $\%$, potassium and alpha-amino $\mathrm{N}$ contents were significantly influenced by the applied K-humate levels in both seasons. Increasing K-humate level gradually resulted in the highest values of sucrose $\%$, while adding 2.5 or 5 or $7.5 \mathrm{~kg} / \mathrm{fed}$ (without significant varying between them) was reduced the contents of potassium and alpha-amino $\mathrm{N}$ in beet roots compared with those that untreated in both seasons. This finding showed that reducing alpha-amino $\mathrm{N}$ content in juice quality may be due to potassium role in increasing the activity of enzymes and concentration of soluble substances in the xylem resulting in limited impurities adsorption by plants Enan et al., (2016). Also, these results are in harmony with those obtained by Olk et al., (2018) who explained that increasing humate substance make up a decrease in sodium and alpha-amino nitrogen amount of sugar beet by increasing of humic acid level.

The results in the same table assured that the differences in boron levels were insignificant in their influence on the three major impurities components (potassium, sodium and alpha-amino $\mathrm{N}$ contents) in sugar beetroots. Raising boron levels from zero to 210 $\mathrm{ppm} /$ fed resulted in a significant increase in sucrose \% amounted to ( 0.23 and 0.42 increases in sucrose), compared to that gained by fertilizing with $140 \mathrm{ppm}$ boron/fed in $1^{\text {st }}$ and $2^{\text {nd }}$ seasons, successively. These results may be assured the vital role of boron element in metabolic translocation possess; this view is in harmony with those obtained by Abbas et al., (2014) and Mekdad (2015).

Table 8. Effect of potassium humate and boron fertilization levels on sucrose \%, potassium, sodium and alfa amino nitrogen of sugar beet in 2018/2019 and 2019/2020 seasons

\begin{tabular}{|c|c|c|c|c|c|c|c|c|}
\hline \multirow{3}{*}{ Treatments } & \multirow{2}{*}{\multicolumn{2}{|c|}{ Sucrose \% }} & \multicolumn{6}{|c|}{ Impurities contents (meq/100 g beet) } \\
\hline & & & \multicolumn{2}{|c|}{ Potassium } & \multicolumn{2}{|c|}{ Sodium } & \multicolumn{2}{|c|}{ Alpha-amino N } \\
\hline & $1^{\text {st }}$ Season & $2^{\text {nd }}$ Season & $1^{\text {st }}$ Season & $2^{\text {nd }}$ Season & $1^{\text {st }}$ Season & $2^{\text {nd }}$ Season & $1^{\text {st }}$ Season & $2^{\text {nd }}$ Season \\
\hline \multicolumn{9}{|c|}{ (A) Potassium humate rate $(\mathrm{kg} / \mathrm{fed})$} \\
\hline 0 & 17.71 & 17.43 & 3.74 & 4.45 & 1.73 & 1.63 & 1.65 & 1.54 \\
\hline 2.5 & 17.97 & 17.65 & 3.56 & 3.42 & 1.67 & 1.59 & 1.52 & 1.35 \\
\hline 5 & 18.34 & 18.12 & 3.41 & 3.36 & 1.60 & 1.57 & 1.26 & 1.26 \\
\hline 7.5 & 19.26 & 19.25 & 3.37 & 3.32 & 1.50 & 1.52 & 1.19 & 1.15 \\
\hline LSD at $5 \%$ level & 0.60 & 0.69 & 0.29 & 0.40 & NS & NS & 0.18 & 0.11 \\
\hline \multicolumn{9}{|c|}{ (B) Boron fertilization level (ppm) } \\
\hline 0 & 17.39 & 17.20 & 3.65 & 3.87 & 1.69 & 1.72 & 1.50 & 1.39 \\
\hline 70 & 18.12 & 17.88 & 3.57 & 3.76 & 1.64 & 1.61 & 1.43 & 1.33 \\
\hline 140 & 18.77 & 18.48 & 3.53 & 3.51 & 1.61 & 1.54 & 1.35 & 1.30 \\
\hline 210 & 19.00 & 18.90 & 3.42 & 3.41 & 1.55 & 1.44 & 1.32 & 1.28 \\
\hline LSD at $5 \%$ level & 0.54 & 0.45 & NS & NS & NS & NS & NS & NS \\
\hline $\mathrm{AxB}$ & NS & $\mathrm{NS}$ & NS & NS & NS & NS & NS & NS \\
\hline
\end{tabular}

4. Sugar lost to molasses, extractable sugar percentages and quality index.

Data averaged over two seasons in Table 9 revealed that fertilizing beet plants with 7.5 and/or $5 \mathrm{~kg} \mathrm{~K}$ humate/fed without significant difference between them was significantly decreased sugar lost to molasses\% compared to that were unfertilized and those fertilized with $2.5 \mathrm{~kg} / \mathrm{fed}$. However, extractable sugar\% and quality index gradually increased by raising K-humate levels from zero to $7.5 \mathrm{~kg} / \mathrm{fed}$. These increases were $(0.96,1.17$ in extractable sugar\%) and $(0.73,0.90$ higher in quality index) comparing with that gained when sugar beet had supplied $5 \mathrm{~kg}$ of $\mathrm{K}$-humate/fed in $1^{\text {st }}$ season and a second one, respectively. The positive effect of the high dose of K-humate had accompanied by a decrease in sugar lost to molasses \%, which was reflected in the highest values of both extractable sugar\% and quality index, this effect could be due to potassium role in increasing enzyme activity and concentration of soluble substances in the xylem, resulting in limited sodium adsorption by plants Rehab et al., (2019).

As for, the effect of boron levels, the data in the same Table cleared that sprayed beet plants with 210 $\mathrm{ppm} / \mathrm{on}$ three times decreased sugar lost to molasses\% in the two growing seasons. On the other hand, spraying beet plants with 140 and/or $210 \mathrm{ppm}$ boron produced a higher percentage of extractable sugar (without significant differences between them) and was satisfactory to reach the higher values of a quality index in both seasons Nemat Alla et al., (2018) and Shritinnahar et al., (2020). 
Table 9. Effect of potassium humate and boron fertilization levels on sugar lost to molasses, extractable sugar percentages and quality index of sugar beet in 2018/2019 and 2019/2020 seasons

\begin{tabular}{|c|c|c|c|c|c|c|}
\hline \multirow[b]{2}{*}{ Treatments } & \multicolumn{2}{|c|}{ Sugar lost to molasses \% } & \multicolumn{2}{|c|}{ Extractable sugar \% } & \multicolumn{2}{|c|}{ Quality index } \\
\hline & $\begin{array}{c}1^{\text {st }} \\
\text { Season }\end{array}$ & $\begin{array}{c}2^{\text {nd }} \\
\text { Season }\end{array}$ & $\begin{array}{c}1^{\text {st }} \\
\text { Season }\end{array}$ & $\begin{array}{c}2^{\text {nd }} \\
\text { Season }\end{array}$ & $\begin{array}{c}1^{\text {st }} \\
\text { Season }\end{array}$ & $\begin{array}{c}2^{\text {nd }} \\
\text { season }\end{array}$ \\
\hline \multicolumn{7}{|c|}{ (A) Potassium humate rate $(\mathrm{kg} / \mathrm{fed})$} \\
\hline 0 & 1.68 & 1.73 & 15.43 & 15.10 & 87.12 & 86.54 \\
\hline 2.5 & 1.62 & 1.54 & 15.74 & 15.51 & 87.59 & 87.85 \\
\hline 5 & 1.52 & 1.51 & 16.22 & 16.02 & 88.44 & 88.35 \\
\hline 7.5 & 1.49 & 1.46 & 17.18 & 17.19 & 89.17 & 89.25 \\
\hline LSD at $5 \%$ level & 0.06 & 0.06 & 0.58 & 0.68 & 0.36 & 0.48 \\
\hline \multicolumn{7}{|c|}{ (B) Boron fertilization level (ppm) } \\
\hline 0 & 1.62 & 1.63 & 15.17 & 14.97 & 87.18 & 86.97 \\
\hline 70 & 1.59 & 1.58 & 15.93 & 15.69 & 87.88 & 87.73 \\
\hline 140 & 1.56 & 1.53 & 16.61 & 16.35 & 88.48 & 88.45 \\
\hline 210 & 1.53 & 1.50 & 16.88 & 16.80 & 88.79 & 88.85 \\
\hline LSD at $5 \%$ level & 0.04 & 0.06 & 0.54 & 0.45 & 0.35 & 0.41 \\
\hline $\mathrm{AxB}$ & NS & NS & NS & NS & NS & NS \\
\hline
\end{tabular}

\section{Root, top and sugar yields/fed.}

Data averaged over the two seasons in Table 10 cleared that root, top and sugar yields/fed were significantly affected by potassium humate levels. A gradual increases in yields of the root, top and sugar/fed as humate rate level increased from zero to $7.5 \mathrm{~kg} / \mathrm{fed}$ was recorded. The increases amounted to $(6.19 \%, 6.31$ $\%$ tons roots) and $(10.96 \%, 16.90 \%$ tons leaves $)$ and $(12.43 \%, 14.13 \%$ tons sugar) compared to beet plants that fertilized with $5 \mathrm{~kg} / \mathrm{fed}$ in the first and second season, respectively. Those increases may be due to increased root fresh and foliage weights/plant Table (4) and root quality traits, in terms of sucrose and extractable sugar percentages Table (7), which are significantly affected by varying potassium humate rates in both seasons. These results are in agreement with that obtained by Shaban et al., (2014) and Rehab et al., (2019).

Table 10. Effect of potassium humate and boron fertilization levels on root yield, top yield and sugar yield of sugar beet in 2018/2019 and 2019/2020 seasons

\begin{tabular}{|c|c|c|c|c|c|c|}
\hline \multirow{2}{*}{ Treatments } & \multicolumn{2}{|c|}{$\begin{array}{c}\text { Root yield/fed } \\
\text { (ton) }\end{array}$} & \multicolumn{2}{|c|}{$\begin{array}{l}\text { Top yield/fed } \\
\text { (ton) }\end{array}$} & \multicolumn{2}{|c|}{$\begin{array}{c}\text { Sugar yield/fed } \\
\text { (ton) }\end{array}$} \\
\hline & $\begin{array}{c}1^{\text {st }} \\
\text { Season }\end{array}$ & $\begin{array}{c}2^{\text {nd }} \\
\text { Season }\end{array}$ & $\begin{array}{c}1^{\text {st }} \\
\text { Season }\end{array}$ & $\begin{array}{c}2^{\text {nd }} \\
\text { Season }\end{array}$ & $\begin{array}{c}1^{\text {st }} \\
\text { Season }\end{array}$ & $\begin{array}{c}2^{\text {nd }} \\
\text { season } \\
\end{array}$ \\
\hline \multicolumn{7}{|c|}{ (A) Potassium humate rate $(\mathrm{kg} / \mathrm{fed})$} \\
\hline 0 & 19.50 & 20.32 & 6.85 & 6.68 & 3.02 & 3.07 \\
\hline 2.5 & 20.79 & 21.45 & 6.99 & 6.79 & 3.28 & 3.33 \\
\hline 5 & 21.33 & 22.51 & 7.30 & 7.16 & 3.46 & 3.61 \\
\hline 7.5 & 22.65 & 23.93 & 8.10 & 8.37 & 3.89 & 4.12 \\
\hline LSD at $5 \%$ & 1.32 & 1.30 & 0.80 & 0.46 & 0.20 & 0.26 \\
\hline \multicolumn{7}{|c|}{ (B) Boron fertilization level (ppm) } \\
\hline 0 & 20.29 & 21.49 & 6.34 & 6.35 & 3.09 & 3.23 \\
\hline 170 & 20.87 & 21.72 & 7.40 & 7.29 & 3.33 & 3.42 \\
\hline 140 & 21.39 & 22.24 & 7.61 & 7.55 & 3.55 & 3.65 \\
\hline 210 & 21.75 & 22.76 & 7.89 & 7.80 & 3.68 & 3.83 \\
\hline LSD at $5 \%$ level & 0.38 & 0.42 & 0.28 & 0.34 & 0.13 & 0.15 \\
\hline $\mathrm{AxB}$ & 0.76 & 0.83 & NS & NS & NS & NS \\
\hline
\end{tabular}


Table 11. Effect of interaction between potassium humate and boron fertilization levels on root yield in 2018/2019 and 2019/2020 seasons

\begin{tabular}{ccccccccc}
\hline \multirow{2}{*}{$\begin{array}{c}\text { Potassium humate rate } \\
\text { (kg/fed) }\end{array}$} & \multicolumn{9}{c}{ Boron fertilization level (ppm /fed) } \\
\cline { 2 - 9 } & $\mathbf{0}$ & $\mathbf{2 0 1 7 / 2 0 1 8}$ season & \multicolumn{4}{c}{$\mathbf{2 0 1 8 / 2 0 1 9}$ season } \\
\cline { 2 - 9 } & 18.43 & 19.07 & 19.65 & 20.86 & 1.50 & 19.87 & 20.36 & 21.56 \\
2.5 & 20.58 & 20.68 & 20.86 & 21.03 & 21.23 & 21.37 & 21.54 & 21.66 \\
5 & 21.28 & 21.28 & 21.39 & 21.46 & 22.23 & 22.45 & 22.58 & 22.77 \\
7.5 & 21.69 & 21.94 & 23.19 & 23.81 & 22.97 & 23.19 & 24.49 & 25.04 \\
\hline LSD at 5\% level & \multicolumn{4}{c}{0.76} \\
\hline
\end{tabular}

As for, the effect of boron levels data in the same Table revealed that yields of root, top and sugar/fed risen steadily by sprayed beet plants with boron levels in both seasons. Raising boron levels from zero to 210 ppm boron/fed was accompanied by a significant increase in yields of root, top and sugar/fed, but with a higher magnitude at the 210-ppm boron than at the 140 ppm boron level. These increases were $(0.36,0.52$-ton roots), (0.28, 0.25-ton leaves) and (0.13, 0.18-ton sugar) over that sprayed with $140 \mathrm{ppm}$ boron in the first and second seasons, respectively. This positive effect was earlier obtained on root diameter, fresh and foliage weights/plant, as well sucrose \% which were reflected on yields of root, top and sugar/fed (Pirzad et al., 2019 and Shritinnahar et al., 2020).

\section{Interaction effect:}

The results in Table 11 showed that the difference in root yield/fed between beets sprayed with $140 \mathrm{ppm}$ and those received $210 \mathrm{ppm}$ boron/fed was insignificant when sugar beet was fertilized with $2.5,5$ and $7.5 \mathrm{~kg}$ $\mathrm{K}$-humate/fed. However, the variance in this trait between these two levels of boron reached the level of significance in the case of unfertilized with humate in both seasons. This has been observed that the highest values of root yield/fed were more clear when plants fertilized with $7.5 \mathrm{~kg}$ humate/fed along with sprayed-by $210 \mathrm{ppm}$ boron in $1^{\text {st }}$ and $2^{\text {nd }}$ season. This finding may point to the role of humic substance in help nitrate uptake from soil and facilitate water use efficiency, in addition to enhancing various microbial and enzymatic processes. Furthermore, potassium role in enzyme activation, protein synthesis, osmoregulation, energy transfer, cation-anion balance and stress resistance by improving nutritional status which is reflected on yield and its components. This view is in agreement with concluded with Enan (2011).

\section{REFERENCES}

A.O.A.C. 2005. Association of Official Analytical Chemists. Official Methods of Analysis, 26th Ed. AOAC International, Washington, D.C. USA

Abbas, M.S., M.H. Dewdar, E.I. Gaber and H.A. AbdElAleem. 2014. Impact of boron foliar application on quantity and quality traits of sugar beet (Beta vulgaris L.) in Egypt. Res. J. Pharma. Biol. Chem. Sci. 5(5): 143-151.

Black, C. A, D. D. Evans, L.E. Ensminger, G.L. Whiteand and F.E. Clark. 1981. Methods of Soil Analysis.Part 2. Pp. 1100. Agron. Inc. Madison. WI., USA.

Cooke, D.A. and R. K. Scott. 1993. The sugar beet crop. Chapman and Hall London. 262-265.

Devillers, P. 1988. Previsoion du sucre melasse Scurries francases 190-200. (C.F. The Sugar Beet Crop. Book).

Dexter, S.T., M.G. Frakes and F.W. Snyder. 1967. A rapid and practical method of determining extractable white sugar as may be applied to the evaluation of agronomic practices and grower deliveries in the sugar

Enan, S.A.A.M. 2011. Effect of transplanting and foliar fertilization with potassium and boron on yield and quality traits of sugar beet sown under saline conditions. J. Biol. Chem. Environ. Sci. 6 (2): 525-546.

Enan, S.A.A.M., A.M. El-Saady and A.B. El-Sayed. 2016. Impact of foliar feeding with alga extract and boron on yield and quality of sugar beet. Egypt. J. Agron. 38 (2) 319-336.

Enan, S.A.A.M., E.F.A.Aly and A. I. Badr. 2016. Effect of humic acid and potassium on yield and quality of some sugar beet varieties in sandy soil. J. Plant Production, Mansoura Univ. 7 (2):289- 297

Gomez, K.A. and A.A. Gomez. 1984. Statistical Procedures for Agricultural Research John Wiley and Sons.International Sci. Publisher, New York, USA. (2 $2^{\text {nd }}$ Ed.): 457-423.

Hartwigsen, J.A. and M. R. Evans. 2000. Humic acid seed and substrate treatments promote seedling root development. HORTSCIENCE. 35(7):1231-1233.

Jackson, M. I. 1973. Soil Chemical Analysis.Prentice Hall Inc. Englewood cliffs, N. J., U.S.A. 
Mekdad, A.A.A. 2015. Sugar Beet Productivity as Affected by Nitrogen Fertilizer and Foliar Spraying with Boron. Int.J.Curr.Microbiol.App.Sci. 4(4): 181-196.

Nemeat Alla. H.A. 2017. Effect of Boron Level and Time of Application on Yield and Quality of Sugar Beet. J. Plant Production, Mansoura Univ. 8(11):1071 - 1075.

Nemeat Alla, H.A., A.H. Sasy and S.A.M. Helmy. 2018. Effect of Potassium humate and Nitrogen Fertilization on Yield and Quality of Sugar Beet in Sandy Soil. J. Plant Production, Mansoura Univ. 9 (4): 333 - 338

Olk, D. C., D. Dinnes, J. R. Scoresby, C. R. Callaway and J. W. Darlington. 2018. Humic products in agriculture: potential benefits and research challenges - a review. J Soil Sediment. 2881-2891.

Pirzed, A., M.M.Mamyandi, R. Khalilzadeh. 2019. Physiological and morphological responses of sugar beet (Beta vulgaris L.) subjected to nano-boron oxide at different growth stages. Acta Biol Szeged. 63(2):103-111.

Rehab, I.F, S.S.El Maghraby, E.E. Kandil and N.Y. Ibrahim. 2019. Productivity and Quality of Sugar Beet in Relation to Humic Acid and Boron Fertilization Under Nubaria
Conditions. ALEXANDRIA SCI. EXCHANGE J.40(1): 115-126.

Shaban, KH.A. H., M. A. F. Eman and A. S. Dalia. 2014. Impact of humic acid and mineral nitrogen fertilization on soil chemical properties and yield and quality of sugar beet under saline soil. J. Soil Sci. and Agric. Eng., Mansoura Univ. 5 (10):1317-1335.

Shritinnahar, B., K., P., Swapan, M.d. Abdul Kader, K. S. Shubroto, K.M. Chandan and A. K. M. Rashadul Islam. 2020. Foliar Application of Boron Boosts the Performance of Tropical Sugar Beet. J Bangladesh Agril Univ. 18(3): 537-544.

Snedecor, G.W. and W.G. Cochran. 1980. Statistical Methods. $7^{\text {th }}$ Ed. The Iowa State Univ. Press Amer. Iowa. USA.

Von Wettstein, D. 1957. Chlorophyll letale and der submikroskopishe formweschselder plastiden. Experimental cell Research. 12: 427. doi:10.1016/0014-4827(57) 901659 . 


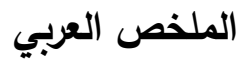 \\ تأثير التسميد بهيومات البوتاسيوم والبورون على محصول وجودة بنجر السكر في التربة الرملية} هيثم السيد أحمد نعدت الله، ابراهيم سليمان هلال الجمل و نادية كامل الصافي

دلت النتائج علي أن الرش بإضافه ــاب جزء في المليون

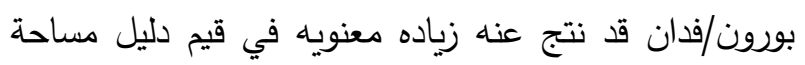
الاوراق، وقطر ووزن الجذور والأوراق الطازجة للنبات.

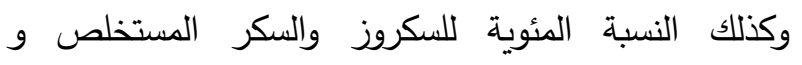

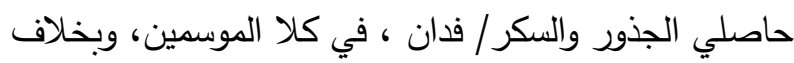

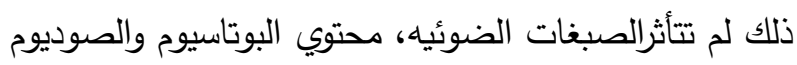

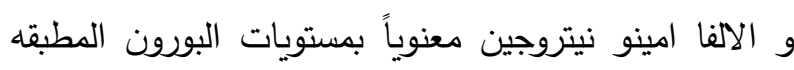

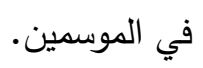
تأترا التفاعل بين مستويات هيومات البوتاسيوم والبورون تأثيرا معنويا علي بعض الصفات المدروسه ، حيث أعطت

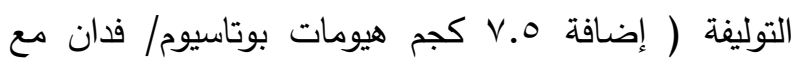

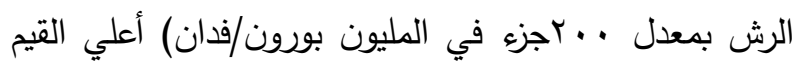

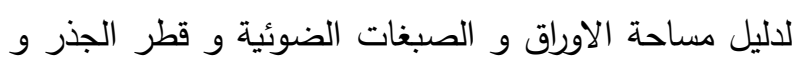
كنلك حاصل الجذور في كلا الموسمين • توصي الدراسه بتسميد بنجر السكر بهيومات البوتاسيوم بمعدل V.0 كجم / للفدان مع الرش الورقي بالبورون بمعدل

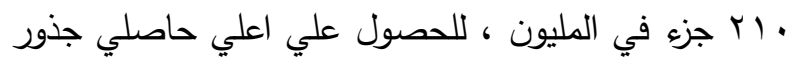
وسكر/فدان تحت ظروف منطقة النوباريه.
أقيمت تجربتان حقليتان في منطقة النوبارية - محافظة

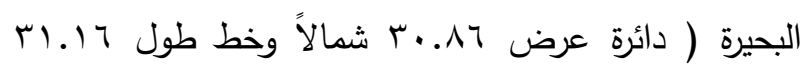

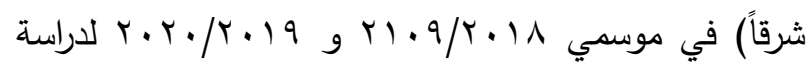

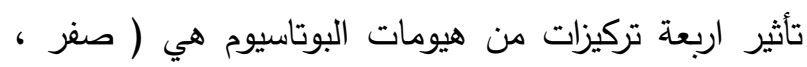

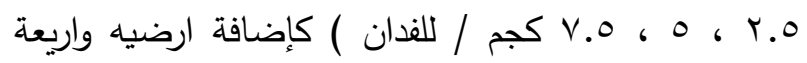

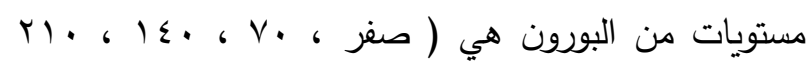

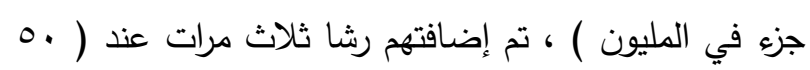

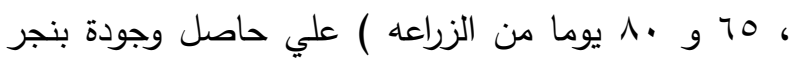

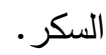

تم استخدام تصميم القطع المنشقة مرة واحدة في ثلاث مكررات حيث تم وضع تركيزات هيومات البوتاسيوم في القطع الرئيسيه بينما تم وضع مستويات البورون في القطع المنشقه. يمكن تلخيص اهم النتائج المتحصل عليها في الاتي:

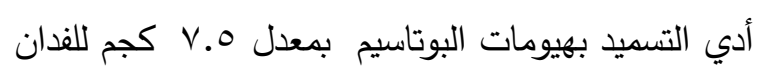

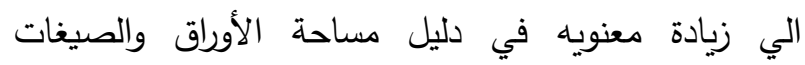

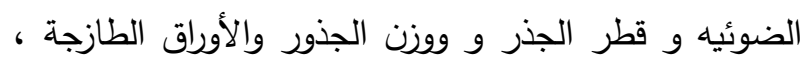
كنلك النسبة المئوية للسكروز و السكر المفقود في المونلاس ومحتوي الجذور من الثوائب (البوتاسيوم والالفا امينو

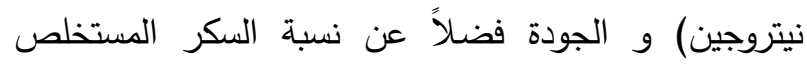

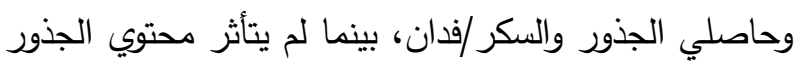

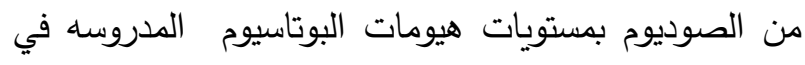

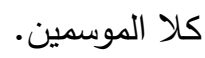

